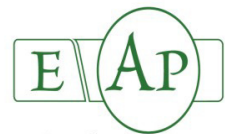

AcademicPres

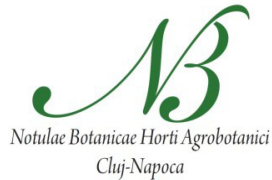

Original Article

\title{
Quality Parameters and Antioxidant Activity of Three Clover Species in Relation to the Livestock Diet
}

\author{
Mirjana P. PETROVIĆ ${ }^{1 *}$, Milan S. STANKOVIĆ ${ }^{2}$, Bojan S. ANĐELKOVIĆ ${ }^{1}$, \\ Snežana Ž. BABIĆ ${ }^{1}$, Vladimir G. ZORNIĆ ${ }^{1}$, Sanja Lj. VASILJEVIĆ 3 , \\ Zora P. DAJIĆ-STEVANOVIĆ \\ IInstitutefor ForageCrops,37251 Globoder, Kruševac,Serbia; mirjanapetrovic@ikbks.com ('correspondingauthor); \\ bojan.andjelkovic@ikbks.com; snezanababic@ikbks.com;vladimir.zomic@ikbks.com \\ ${ }^{2}$ University of Kragujevac, Faculty of Sciences, Institutefor Biology andEcology, Radoja Domanovica 12,34000Kragujevac, Serbia; mstankovic@kg.ac.ss \\ 3Institute ofFieldandVegetableCrops,Maksima Gorkog30,21000NoviSad,Serbia; sanja.vasiljevic@nsseme.com \\ ${ }^{4}$ University of Belgrade, Faculty of Agriculture, Institute of Field andVegetable Crops, Nemanjina 6, 11080, Beograd-Zemum, Serbia; daji@@agrif.bgrac.rs
}

\begin{abstract}
Products of metabolism that are directly involved in growth, development and reproduction and also secondary products of metabolism were studied in 16 natural populations of three species of the genus Trifolium (T. repens - four populations, $T$. alpestre - three populations, T. pannonicum - nine populations), collected from the central Balkans region, i.e. territory of Serbia. Statistical analysis showed the presence of variability in all species of the test material. The best quality of dry matter, estimated by the ratio of crude protein and crude fiber, was achieved in the populations of white clover. In this species, average protein content was $216.4 \mathrm{~g} \mathrm{~kg}^{-1}$ while the average content of crude fiber was $222.4 \mathrm{~g} \mathrm{~kg}^{-1}$. The highest average content of total phenols $\left(77.9 \mathrm{mg} \mathrm{GA} \mathrm{g}^{-1}\right)$, flavonoids $\left(159.7 \mathrm{mg} \mathrm{Ru} \mathrm{g}^{-1}\right)$ and antioxidant activity $\left(70.2 \mu \mathrm{g} \mathrm{ml}^{-1}\right)$ was measured in populations of T. pannonicum by phytochemical analysis of aerial parts of plants. The content of secondary metabolites and antioxidant activity in other species were extremely low. Populations of $T$. pannonicum were notable for fodder quality and antioxidant activity: CS091 with $186.2 \mathrm{~g} \mathrm{~kg}^{-1}$ of crude protein and antioxidant activity of $55 \mu \mathrm{g} \mathrm{ml}^{-1}$; RA123 with $175.6 \mathrm{~g} \mathrm{~kg}^{-1}$ of crude protein and a high level of antioxidant activity of $44.8 \mathrm{ug} \mathrm{ml}^{-1}$. It can be concluded that the selection of these populations may lead to creation of different varieties of fodder crops that could give safe animal feed and would be suitable for growing under adverse conditions of mountainous climate.
\end{abstract}

Keywords: alpine clover, fodder quality, Hungarian clover, phenolic compounds, white clover, wild populations

\section{Introduction}

Fresh, dried or conserved, forage legumes are highly suitable for use as voluminous fodder in the animal diet because of their richness in proteins, vitamins, and mineral matter (Vasiljević et al., 2009). The fact that they are being exploited in the process of grazing, through mowing, and for the preparation of preserved animal feed allows their usage throughout the year. Removal of plants in budding phase and at the beginning of inflorescence (when the proportion of leaves is larger) gives the mass of high nutritional value with a very favorable ratio of crude protein and crude fiber (Đordević and Dinić, 2007). As the plant ages the amount of leaves decreases while the amount of crude fiber i.e. lignin (which is its insoluble part) in the stems increases as well as the amount of structural polysaccharides (Vasiljević $e$ al.,2011). Abundance of vitamins and minerals present in legumes (Marković et al., 2014) are very important for the development of the skeleton of young animals. In addition, legumes
(Fabaceae or Leguminosae family) have great importance in natural ecosystems as they enrich the soil with nitrogen (Rasmussen $e t$ al., 2012) (thus reducing the use of mineral fertilizers); improve its structure by creating favorable conditions for the development of other species and are important as a honey plant (Nicholls and Altieri, 2013). One of the most significant genera of this family is genus Trifolium (Abberton and Thomas, 2011).

Genus Trifolium includes about 240 species (Zohary and Heller, 1984), only a small number of which are cultivated. In addition to well-known species which are widespread on all continents because of wide and traditional application (red, white, alsike clover) the other representatives of the genus are getting more attention in recent studies. As stated by Conterato et al. (2010) in the temperate and subtropical climate conditions, other representatives of this genus are successfully used, in agricultural purposes.

Further process of selection and improvement of new varieties with better nutritive characteristics and productivity is enabled by wild population's examination (Boller and Greene, 2010). 
202

In addition to the utilization of natural populations of this genus in the formation of high-quality and productive varieties for livestock feed, species of the genus Trifolium are, also a source of secondary metabolites which have application in traditional and clinical medicine, as well as in pharmacy (Wu et al., 2003; Vlaisavljević et al., 2014). Secondary metabolites are known for their strong biological activity, including improvement of quality of both human and animal diet. It is known that red clover isoflavones are used in HRT, for the prevention of diseases that occur in menopause in women (Overk et al., 2005). In the study by Oleszek et al. (2007) it was discovered that the species T. heldreichianum, T. scabrum and $T$. subterraneum have extremely high content of isoflavones (more than red clover), which indicates the necessity of studying the representatives of this genus in wild flora. Some species of the genus Trifolium contain high levels of isoflavones. Except for the alleviation of symptoms in women who are in menopause, isoflavones are very important for their biological activity in animals. The use of animal feed with high content of isoflavones very often disrupts normal reproductive cycle in sheep. On the other hand, isoflavones may have some favorable effects in animals for fattening. Lambs fed on red clover, which a higher content of isoflavones had, gained weight more quickly than when they fed on a mixture of red clover and ryegrass, with a low content of isoflavones (Moorby et al., 2004). Selection for lower phytoestrogens levels in this crop has been effective and is directed towards the development of genotypes suitable for sheep nutrition for the purposes of improved fertility (McDonald et al., 1994). Because some clover species e.g. T. repens and $T$. alpestre are used extensively for grazing, future breeding program should be focused on creating varieties with low content of isoflavones.

The plant material used in this study originated from the Balkan Peninsula, which is considered an extension of the Mediterranean region, and is characterized by the presence of a large number of plant taxa. Samples were collected from populations of three species: $T$. repens, T. alpestre and T.pannonicum.

T. repens $\mathrm{L}$. is a part of European flora also grown in other parts of the world, and it is significant in agriculture worldwide as "the most often cultivated species of the genus Trifolium" (Ellison et al., 2006). Its fodder has high quality with high content of crude protein. It is used in Turkish traditional medicine (Sabudak and Guller, 2009) and it is characterized by presence of a large quantity of active substances from the group of secondary metabolites (Ponce et al., 2004).

T. alpestre L. (alpine clover) is widespread in middle and southern Europe, Siberia, Ural and Asia Minor. This perennial plant is important part of natural meadows and shows very good potential for forage crop communities (Pelikán et al., 2005).

T. pannonicum Jacq. (Hungarian clover) occurs mostly in the central Europe and Ukraine, and it is less present in Italy, in the Balkans, and in Asia Minor. It is used in Anatolia (Turkey) as forage feed for hay preparation (Şahin et al., 2009). Presence of secondary metabolites with antioxidant activity was also recorded for this species sampled from populations from the Balkan Peninsula (Godevac et al., 2008).

In order to appropriately assess the dry matter quality of populations of species $T$. alpestre and $T$. pannonicum, the comparison was performed with wild populations of $T$. repens. These species have very rarely been represented in previous researches of fodder quality, so it is interesting to examine their potential for application in the highland area of the Balkans. It is known that instead of using synthetic antibiotics, there is also an option to add plant products to concentrated animal feed, which would have positive effects on both the processes inside rumen, and peripheral metabolism of animals (Greathead, 2003). In addition, increased antioxidant activity indicates the safety of livestock feed, which has indirect influence on human health through dairy products and meat.

In this research metabolism products were analyzed in total of 16 natural populations of three clover species, the Trifolium repens, $T$. alpestre and T.pannonicum. The aim of the study was to evaluate the populations and single out those with desirable traits considering quality parameters and secondary metabolites with an antioxidant activity. Also, the aim was to compare quality parameters of $T$. alpestre and T.pannonicum with those of T. repens, and to assess their potential to be selected for quality in the future, or used for animal nutrition.

\section{Materials and Methods}

\section{Biologicalmaterial}

The seeds were obtained from the seed collection of the Institute for forage crops, Kruševac, R of Serbia (Table 1) collected in hilly and mountainous regions of Serbia. Total of 16 populations from the existing collection were included in the analysis. The field trial consisted of a large number of wild populations, and for the purpose of the analysis populations that under field conditions were the most persistent were selected (16 populations of three Trifolium species).

\section{Experiment}

The experiment was conducted on the property of the Institute for forage crops, Kruševac (Globoder) (altitude $150 \mathrm{~m}$, $43^{\circ} 34^{\prime} 55^{\prime \prime}$ latitude, $21^{\circ} 34^{\prime} 8^{\prime \prime}$ longitude). The experiment started at the beginning of October 2009 and lasted until 2011.

Table 1. Origin of plant material: species, population code, latitude, longitude and elevation

\begin{tabular}{|c|c|c|c|c|}
\hline Population code & Samplingsites & Latitude & Longitude & Elevation $(\mathrm{m})$ \\
\hline \multicolumn{5}{|c|}{ Trifolium repens } \\
\hline CS 122 & Kriva Reka & N43'22.7079' & E020 $52.5225^{\prime}$ & 1216 \\
\hline FG020 & Iriški Venac & $\mathrm{N} 45^{\circ} 05.5418^{\prime}$ & E019 $52.0775^{\prime}$ & 196 \\
\hline FG025 & Vrdnik & N45 $07.8368^{\prime}$ & E019 $46.7754^{\prime}$ & 254 \\
\hline RA089 & Osoje & $\mathrm{N} 43^{\circ} 12.1248^{\prime}$ & E020 17.0448' & 890 \\
\hline \multicolumn{5}{|c|}{ Trifolium alpestre } \\
\hline CS068 & Mitrovo Polje & N43 $30.6158^{\prime}$ & E020 $52.6651^{\prime}$ & 677 \\
\hline CS091a & Stanišinci 1 & $\mathrm{~N} 43^{\circ} 32.6246$ & E020 $53.9164^{\prime}$ & 911 \\
\hline CS $105 a$ & Ravnište & $\mathrm{N} 43^{\circ} 16.1452^{\prime}$ & E020 $52.3682^{\prime}$ & 1054 \\
\hline \multicolumn{5}{|c|}{ Trifoliumpannonicum } \\
\hline CS091b & Stanišinci 1 & N43 32.6246 & E020 $53.9164^{\prime}$ & 911 \\
\hline CS $105 b$ & Ravnište & $\mathrm{N} 43^{\circ} 16.1452^{\prime}$ & E020 $52.3682^{\prime}$ & 1054 \\
\hline CS 119 & Ploča & $\mathrm{N} 43^{\circ} 26.5037^{\prime}$ & E020 $53.0167^{\prime}$ & 1186 \\
\hline CS 131 & Bela reka & N43ํ⒈5978' & E020 $51.7979 '$ & 1310 \\
\hline CS 146 & Srebrnac & N43ํ⒙9151' & E020 $51.2528^{\prime}$ & 1465 \\
\hline ES047 & Boljevac 2 & N43ํำ.8262' & E022 $03.6603^{\prime}$ & 470 \\
\hline ES059 & Čestobrodica 1 & N43 $50.5721^{\prime}$ & E021 $40.5952^{\prime}$ & 587 \\
\hline RA 100 & Donja Vapa & N43ํำ.5624' & E020 01.7826 & 996 \\
\hline RA 123 & Duga Poljana & $\mathrm{N} 43^{\circ} 16.1972^{\prime}$ & E020 $13.4084^{\prime}$ & 1230 \\
\hline
\end{tabular}

abbreviation of each population consist of two parts: letters that present part of territory where population samples were collected (CS - Central Serbia, ES Eastern Serbia, RA - Area of Raška, TA - Tara) and three numbers as altitude explanation (for example: $025 \approx 250 \mathrm{~m}, 122 \approx 1220 \mathrm{~m}$ ). 
The experimental area has characteristics of a temperate continental climate, with the average annual temperature of 10.9 ${ }^{\circ} \mathrm{C}$ and the average precipitation of $650 \mathrm{~mm}$. The type of soil is degraded alluvial, with $\mathrm{pH} 6.57$ in $\mathrm{KCl}$, organic matter content of $2.52 \%$, available $\mathrm{P}$ content of $6.60 \mathrm{ppm}$ and available $\mathrm{K}$ of 24.05 ppm.

In order to break the dormancy, seeds were scarified (mechanical damaging by sandpaper) and germinated in plant pots. When plants reached the stadium of 34 permanent leaves, they were transplanted to the nursery. Each population was planted in one row (60 individuals per population). The distance between plants in a row was $60 \mathrm{~cm}$. The distance between rows was also $60 \mathrm{~cm}$.

\section{Laboratory analysis of parameters of quality}

For the analysis of forage crops quality, plants of all populations were cut (at the height of $5 \mathrm{~cm}$ ) from May to the beginning of June $(2010,2011)$ in the phase of initial flowering. For each of examined populations, three average bulk green mass samples were taken and dried during $48 \mathrm{~h}$ at $60^{\circ} \mathrm{C}$. Each bulk sample contained 11-12 of single plants of the same height and developmental phase. Basic parameters of forage quality quantity of crude protein, crude fiber, crude fat, ash and NFE (Nitrogen Free Extract) were analyzed from dry samples of each population by Weende system (AOAC,1990). The samples were ground on a mill with a sieve diameter of $2 \mathrm{~mm}$ and laboratory cyclone mill with a sieve diameter of $1 \mathrm{~mm}$. Crude ash was determined by searing at $550^{\circ} \mathrm{C}$. The content of crude protein was determined indirectly from the amount of total nitrogen, measured by the Kjeldahl method modified by Bremner, multiplied by factor 6.25 . Crude fiber content was determined by refluxing in dilute base followed by dilute acid. Crude fat content was determined by method of Soxlet. The amount of nitrogen free extract in samples was determined as a difference between 1000 and amounts of crude ash, crude protein, crude fiber and crude fat.

\section{Preparation of plant extracts}

For the analysis of secondary metabolites and antioxidant activity, the bulk samples were prepared, containing 3-5 representative (fully developed) plant individuals. Plant material was air dried in thin layer in a shadow, at the temperature of 18$22{ }^{\circ} \mathrm{C}$ and air humidity of $55-65 \%$. The drying process was regularly controlled and the damaged or discolored samples were removed. The drying process lasted for 7 days and, after its completion, the plant material was ground and stored in the dark stained glass jars.

Prepared plant material $(10 \mathrm{~g})$ was extracted with $200 \mathrm{ml}$ of methanol and stored at room temperature. After $24 \mathrm{~h}$, the infusions were filtered with Whatman No. 1 filter paper and residues were re-extracted with equal volume of solvents. After $48 \mathrm{~h}$, the process was repeated. Combined supernatants were evaporated to dryness under vacuum at $40{ }^{\circ} \mathrm{C}$ using Rotary evaporator

\section{Determination of total phenolic content}

The total phenolic content was determined by spectrophotometric method (Singleton et al., 1999). The reaction mixture was prepared by mixing $0.5 \mathrm{ml}$ of methanol solution $\left(1 \mathrm{mg} \mathrm{ml}^{-1}\right)$ of extract, $2.5 \mathrm{ml}$ of $10 \%$ Folin-Ciocalteu's reagent dissolved in water and $2.5 \mathrm{ml} 7.5 \% \mathrm{NaHCO}_{3}$. The samples were incubated at $45^{\circ} \mathrm{C}$ for $15 \mathrm{~min}$. The absorbance was determined at $\lambda \max =765 \mathrm{~nm}$. The total phenolic content was expressed in terms of gallic acid equivalent (mg of GA g $\mathrm{g}^{-1}$ of extract).

\section{Determination offlavonoid concentrations}

The concentration of flavonoids was determined by using spectrophotometric method (Quettier et al., 2000). The sample contained $1 \mathrm{ml}$ of methanol solution of the extract in the concentration of $1 \mathrm{mg} \mathrm{ml}^{-1}$ and $1 \mathrm{ml}$ of $2 \% \mathrm{AlCl}_{3}$ solution dissolved in methanol. The samples were incubated for an hour at room temperature. The absorbance was determined at $\lambda \max =$ $415 \mathrm{~nm}$. Concentration of flavonoids in extracts was expressed in terms of rutin equivalent ( $m g$ of $\mathrm{Ru}^{-1}$ of extract).

\section{Evaluation of DPPH scavenging activity}

The ability of the plant extract and reference substance to scavenge $\mathrm{DPPH}^{+}$free radicals was assessed by using the method adopted with suitable modifications upon Kumarasamy et al. (2007). The stock solution of the plant extract was prepared in methanol to achieve the concentration of $1 \mathrm{mg} \mathrm{ml}^{-1}$. Dilutions were made to obtain concentrations of 500, 250, 125, 62.5, $31.25,15.62,7.81,3.90,1.99,0.97 \mu \mathrm{g} \mathrm{m}^{-1}$. Diluted solutions (1 $\mathrm{ml}$ each) were mixed with $1 \mathrm{ml}$ of DPPH methanolic solution $\left(80 \mu \mathrm{g} \mathrm{m}^{-1}\right)$. After $30 \mathrm{~min}$ in darkness at room temperature $\left(23^{\circ} \mathrm{C}\right)$, the absorbance was recorded at $517 \mathrm{~nm}$. The control samples contained all the reagents except the extract. The percentage inhibition was calculated using equation: \% inhibition $=100 \times$ (A of control - A of sample) $/$ A of control $)$.

\section{Chemicals}

Methanol and sodium hydrogen carbonate were purchased from "Zorka pharma" Šabac, Serbia. Gallic acid, rutin hydrate and 2,2-dyphenyl-1-picrylhydrazyl (DPPH) were obtained from Sigma Chemicals Co., St Louis, MO, USA. Folin-Ciocalteu phenol reagent and aluminium chloride hexahydrate $\left(\mathrm{AlCl}_{3}\right)$ were purchased from FlukaChemie AG, Buchs, Switzerland. All other solvents and chemicals were of analytical grade.

\section{Statistical analysis}

For each chemical features and antioxidant activity, one-way analysis of variance (ANOVA) was used to examine differences in mean values among populations. When differences were noted, multiple comparisons were performed base on LSD test. Differences were considered significant at $\mathrm{p}<0.01$. Principal component analysis (PCA) was applied to search for a general pattern in the measured variables. The statistical analyses were performed using the program STATISTICA 10 (StatSoft, Inc., Tulsa, OK, USA).

\section{Results and Discussion}

\section{Analysis of parameters of quality}

Considering nutrition value of a fodder plant, the content of crude proteins and crude fiber are among the most important parameters. All together, the examined nutritive parameters could better determine the exact quality of investigated native clover populations (Table 2).

The variance analysis and LSD test have showed the existence of statistically significant differences among the populations of every species for all parameters of dry matter quality. 
204

Statistical analysis showed that all populations of white clover (except one - CS122) were uniform for the protein content. Content of the crude protein in populations of the white clover ranged from $200 \mathrm{~g} \mathrm{~kg}^{-1}$ (population CS122) to $223.0 \mathrm{~g} \mathrm{~kg}^{-1}$ (FG020). Obtained results for crude protein in white clover are in accordance with findings of Đukić $e t$ al. (2009) for several Serbian varieties, having about $20 \%$ of crude protein of the total dry matter. Marshall et al. (2004) got higher protein values on white clover varieties (236.5 g kg average).

The average protein content was higher compared to the other two studied species, while the crude fiber content was the lowest. Content of crude fiber for populations of $T$. repens ranged from $192.8 \mathrm{~g} \mathrm{~kg}^{-1}$ (RA089) to $243.1 \mathrm{~g} \mathrm{~kg}^{-1}$ (FG020). The most favorable ratio of crude protein and crude fiber and the highest crude fat content occurred in populations RA089, which stands out as a potential material for breeding purposes. The average crude protein content was lower while the average crude fiber content was higher in T. alpestre and T.pannonicum compared with white clover.

T. alpestre populations exhibited somewhat lower quality of the dry matter. The highest protein content in the studied sampling phase was found in population CS105a $\left(172.7 \mathrm{~g} \mathrm{~kg}^{-1}\right)$ and it was statistically significantly different from other populations. The same population had medium values for crude fiber, fat and ash.

The lowest and the highest crude fiber values in alpine clover were found for populations CS091a (289.3 $\left.\mathrm{g} \mathrm{kg}^{-1}\right)$ and CS068 $\left(325.7 \mathrm{~g} \mathrm{~kg}^{-1}\right)$, respectively. Nevertheless, when compared with wild populations of the red clover with crude proteins and crude fiber ranging from $139 \mathrm{~g} \mathrm{~kg}^{-1}$ to $195.4 \mathrm{~g} \mathrm{~kg}^{-1}$, and from $249.5 \mathrm{~g} \mathrm{~kg}^{-1}$ to $384.9 \mathrm{~g} \mathrm{~kg}^{-1}$, respectively (Petrović et al., 2014), values obtained for alpine clover populations are of satisfactory quality as animal feed. A small number of sprouts and low plant height makes alpine clover useless for the use as a monoculture. However, as part of multicomponent mixtures, it ensures a steady yield in the long term period, also, the maintenance of a stable ecosystem, provides purification of water in a particular area and prevents erosion of deforested areas (Pelikán et al., 2005).
Considering the habitus of $T$. pannonicum plants, the high proportion of stems in the overall green mass and the presence of dense trichome cover on the stems and leaves, (which contains matters indigestible for an animal) obtained results of the crude protein content are very favorable. The average value of crude protein for populations of T. pannonicum was $171.6 \mathrm{~g} \mathrm{~kg}^{-1}$, which is higher value than it was obtained for some alfalfa and red clover varieties (Tomić et al., 2005). Percentage of crude fiber in populations of $T$. pannonicum was noticeably higher in comparison with other two species, ranging from $278.5 \mathrm{~g} \mathrm{~kg}^{-1}$ (population CS091b) to $383.7 \mathrm{~g} \mathrm{~kg}^{-1}$ (CS146).

Population of $T$. pannonicum that statistically significantly differed by high protein content and lower cellulose content was CS091b. In the entire set of analyzed populations of Hungarian clover, this population can be considered as the most prosperous for future selection programs. The average values of protein and crude fiber in Hungarian clover (Table 2) are consistent with the results by Szabo (1987) in studies of Romanian populations of $T$. pannonicum.

Slightly lower values of crude protein (138.0 - $\left.142.2 \mathrm{~g} \mathrm{~kg}^{-1}\right)$ were obtained while monitoring natural populations of this species by Lugic et al. (2005). Some of the most up to date results of $T$. pannonicum originate from research of Vilčinskas and Dabkevičiene $(2009,2010)$. Compared to before mentioned researches, our results show somewhat higher values of crude protein in the examined material.

The positive impact on the feed quality of the Hungarian clover could be achieved by cutting in the budding phenophase. In this phenophase the amount of leaves, which are the parts of the plant with the highest quality and the most easily digestible, is at its highest. As the plant matures the percentage of the stem as well as the percentage of indigestible matter increases. By harvesting at the right time, the percentage of protein could increase and the percentage of fiber might decrease. This would allow its broader use in the forage production, especially on unfavorable soils where T. pannonicum could be grown for decades by undersowing.

Table 2. Average values of crude: ash, protein, fiber, fat and NFE/( $\left.\mathrm{g} \mathrm{kg}^{-1}\right)$ of 16 wild populations of three species of genus Trifolium

\begin{tabular}{|c|c|c|c|c|c|}
\hline Population & Crude ash & Crude proteins & Crude fiber & Crude fat & NFE \\
\hline \multicolumn{6}{|c|}{ Trifolium repens } \\
\hline CS 122 & $144.1 \pm 3.1 \mathrm{abc}$ & $200 \pm 2.62 b$ & $239 \pm 3.75 g$ & $23.5 \pm 0.8 \mathrm{~cd}$ & $393.4 \pm 10.3 \mathrm{a}-\mathrm{d}$ \\
\hline FG 020 & $141.7 \pm 0.1 \mathrm{bcd}$ & $223 \pm 1.85 \mathrm{a}$ & $243.1 \pm 3.00 \mathrm{~g}$ & $22.5 \pm 0.53 \mathrm{de}$ & $369.7 \pm 5.48$ b-e \\
\hline FG 025 & $147.4 \pm 0.22 a b c$ & $220.5 \pm 7.05 \mathrm{a}$ & $214.6 \pm 3.30 \mathrm{~h}$ & $18.9 \pm 0.58 \mathrm{fg}$ & $398.6 \pm 11.2 a b c$ \\
\hline RA 089 & $138.2 \pm 4.63 \mathrm{~cd}$ & $222 \pm 0.01 \mathrm{a}$ & $192.8 \pm 6.39 \mathrm{i}$ & $25.9 \pm 0.41 \mathrm{~b}$ & $421.1 \pm 11.4 \mathrm{a}$ \\
\hline Average & 142.8 & 216.4 & 222.4 & 22.7 & 395.7 \\
\hline \multicolumn{6}{|c|}{ Trifolium alpestre } \\
\hline CS 068 & $98.7 \pm 2.11 \mathrm{f}$ & $147.7 \pm 0.2 \mathrm{gh}$ & $325.7 \pm 7.06 c$ & $20.9 \pm 0.63 \mathrm{e}$ & $407 \pm 10 \mathrm{ab}$ \\
\hline CS 091a & $132.8 \pm 5.80 \mathrm{~d}$ & $141.8 \pm 2.82 \mathrm{~h}$ & $289.3 \pm 6.61$ ef & $30.4 \pm 1.24 \mathrm{a}$ & $405.7 \pm 16.5 \mathrm{ab}$ \\
\hline CS $105 a$ & $101.1 \pm 3.55 \mathrm{f}$ & $172.7 \pm 2.74 c-f$ & $316.7 \pm 3.82 \mathrm{~cd}$ & $26.3 \pm 0.57 b$ & $383.2 \pm 10.7$ a-e \\
\hline Average & 110.9 & 154.1 & 310.6 & 25.9 & 398.6 \\
\hline \multicolumn{6}{|c|}{ Trifolium pannonicum } \\
\hline CS 091b & $153.7 \pm 3.33 \mathrm{a}$ & $186.2 \pm 3.4 \mathrm{bc}$ & $278.5 \pm 0.62 f$ & $20.7 \pm 0.6 \mathrm{ef}$ & $360.9 \pm 7.9 \mathrm{c}-\mathrm{f}$ \\
\hline CS $105 b$ & $104.6 \pm 2.68 \mathrm{ef}$ & $162.8 \pm 7.31$ ef & $329 \pm 3.53 c$ & $21.2 \pm 0.05 \mathrm{e}$ & $382.4 \pm 13.6$ a-e \\
\hline CS 119 & $139.7 \pm 5.25 \mathrm{bcd}$ & $177 \pm 8.13 \mathrm{~cd}$ & $316.2 \pm 12.02 \mathrm{~cd}$ & $18.6 \pm 0.31 \mathrm{~g}$ & $348.5 \pm 25.71 \mathrm{ef}$ \\
\hline CS 131 & $103.8 \pm 1.83 \mathrm{ef}$ & $159.7 \pm 4.96 \mathrm{fg}$ & $355.6 \pm 10.30 \mathrm{~b}$ & $25.6 \pm 0.65 b$ & $355.3 \pm 17.74 \mathrm{def}$ \\
\hline CS 146 & $98.8 \pm 2.13 \mathrm{f}$ & $170.9 \pm 7.77 \mathrm{def}$ & $383.7 \pm 10.62 \mathrm{a}$ & $24.6 \pm 0.97 b c$ & $322 \pm 21.49 \mathrm{fg}$ \\
\hline ES 047 & $140.6 \pm 4.35 \mathrm{bcd}$ & $162.3 \pm 1.57$ ef & $305.6 \pm 0.73 \mathrm{de}$ & $21.0 \pm 0.95 \mathrm{e}$ & $370.5 \pm 7.61 b-e$ \\
\hline ES 059 & $147.6 \pm 3.07 a b c$ & $186.0 \pm 3.77 \mathrm{c}$ & $302.0 \pm 8.00 \mathrm{de}$ & $17.9 \pm 0.08 \mathrm{~g}$ & $346.5 \pm 14.92 \mathrm{ef}$ \\
\hline RA 100 & $149 \pm 6.07 \mathrm{ab}$ & $164.2 \pm 7.16 \mathrm{def}$ & $375.8 \pm 7.11 \mathrm{a}$ & $17.4 \pm 0.67 \mathrm{~g}$ & $293.6 \pm 21.00 \mathrm{~g}$ \\
\hline RA 123 & $113 \pm 0.41 \mathrm{e}$ & $175.6 \pm 3.04 \mathrm{cde}$ & $289.2 \pm 4.77$ ef & $22.4 \pm 0.80 \mathrm{de}$ & $399.8 \pm 9.01 \mathrm{abc}$ \\
\hline Average & 127.9 & 171.6 & 326.2 & 21.0 & 353.3 \\
\hline
\end{tabular}


Assessment of population variability of studied products of metabolism that are directly involved in growth, development and reproduction

The results of PCA for fodder quality parameters indicate that the set of dry matter variables explained $82.6 \%$ of the overall variability along the first two axes (Fig. 1).

The first principal component axis accounted for $47.8 \%$ of the observed variation. It was strongly and positively correlated with crude fibre and negatively correlated to crude proteins and ash. The second principal component axis (34.8\%) was correlated to NFE and fat.

The first principal component axis separated T. repens, located on the left side of the graph, from $T$. alpestre and $T$. pannonicum, found on the right. The second principal component axis separated T.pannonicum from T. alpestre.

\section{Secondary metabolites concentration}

In all species, populations were statistically significantly different for the content of total phenols and flavonoids as well as antioxidant activity.

\section{Concentration of totalphenolic compounds}

Quantity of total phenolic compounds in extracts of 4 populations of species $T$. repens ranged from 29.0 to $43.8 \mathrm{mg} \mathrm{GAg}$ ${ }^{1}$ of dry matter (Table 3). Total phenolic compounds in extracts of alpine clover populations were in range of $38.5-86.1 \mathrm{mg} \mathrm{GA} \mathrm{g}^{-1}$ of dry matter. In nine examined populations of the Hungarian clover, the lowest content of the total phenolics was found in population CS119 (53.7 $\mathrm{mg} \mathrm{GA} \mathrm{g}^{-1)}$, whereas the highest value of $120.05 \mathrm{mg}$ $\mathrm{GA} \mathrm{g}^{-1}$ was determined for population assigned as CS091b. These results showed that the samples of Hungarian clover have the highest potential for total phenols exploitation.

In the recent studies of the phenolic compounds in the clover species, a range of secondary metabolites was reported, including protocatechuic, p-hydroxybenzoic, genistic, caffeic, p-coumaric, ferulic and salicylic acids (Kicel, Wolbis, 2006) which were identified as the main active substances in above-ground parts of the T. repens. Oleszek et al. (2007) used UPLC Analyses and got lower total phenols content in aerial part of all three mentioned species.

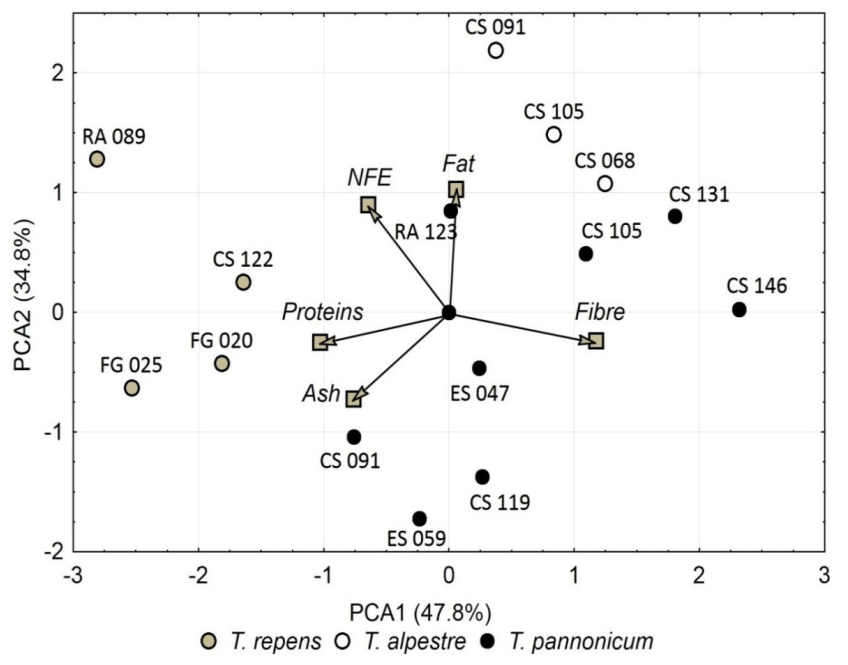

Fig. 1. PCA score and loading biplot based on the fodder quality parameters of three Trifolium species

\section{Concentration offlavonoids}

The presence of flavonoids is very significant in human as well as in animal diet (Kolodziejczyk-Czepas, 2012). Concentration of flavonoids in extracts of samples in white clover populations ranged from 31.2 to $59.7 \mathrm{mg} \mathrm{Ru} \mathrm{g}^{-1}$ of dry matter. Concentration of flavonoids in alpine clover populations was significantly higher, ranging from $60.1 \mathrm{mg} \mathrm{Ru} \mathrm{g}^{-1}$ (CS105) to $130.9 \mathrm{mg} \mathrm{Ru} \mathrm{g}^{-1}$ (CS068) of dry matter. In populations of the species T. pannonicum, concentration of flavonoids ranged from 68.8 (RA100) to even $351.65 \mathrm{mg} \mathrm{Rug}^{-1}$ of dry matter (CS091). In comparative study of isoflavones (subgroup of flavonoids) in above-ground parts of the Trifolium species, it was concluded that $T$. pannonicum contains higher isoflavone levels than the T. repens (Butkute et al., 2012), similarly to our results for flavonoids in these species.

\section{Antioxidant activity}

Values of the antioxidant activity for white clover populations were rather low, ranging from 919.14 to $446.1 \mu \mathrm{g} \mathrm{m} \mathrm{m}^{-1}$. Low phenolic and flavonoids content was followed by low antioxidant activity in white clover material.

Antioxidant activity in Hungarian clover was also low (from 695.5 in CS105 to $272.9 \mathrm{\mu g} \mathrm{ml}^{-1}$ in CS091a). Nevertheless, populations of Hungarian clover exhibited good ability for scavenging of free radicals, where the weakest capacity was showed by the population RA100 $\left(125.57 \mathrm{\mu g} \mathrm{m}^{-1}\right)$, and the strongest antioxidant capacity by the population RA123 $\left(44.84 \mathrm{~g} \mathrm{~m} \mathrm{~m}^{-1}\right)$. The content of total phenols and flavonoids was significantly higher in the population CS091 but the antioxidant activity was statistically significantly lower compared with the population RA123. This can be explained by the fact that the ability to neutralize free radicals depends on the compounds that cannot be assigned to the phenolic group. This result makes the population RA123 noteworthy for the further research. Also high values of flavonoids in a population CS091 are significantly higher than values obtained for the genus Teucrium which was used in folk medicine for centuries (Stanković et al., 2011). Further research should be directed to the examination of possible application of this species for therapeutic purposes, especially populations CS091 and RA123.

\section{Assessment of population variability of studied secondary metabolites}

PCA analysis for studied secondary metabolites showed that the first principal component had the eigenvalue of 2.46 , and accounted for $82 \%$ of the variability in the data set. The second PC had eigenvalue of 0.37 and accounted for $12.3 \%$ of the total variance.

The first principal component axis was negatively correlated with all three studied secondary metabolites. It separated $T$. pannonicum, on the left side of the graph, from $T$. repens and $T$. alpestre populations. This separation was due to better values obtained in T.pannonicum compared to T. repens and T. alpestre.

Contemporary trends include the use of safe animal feed, in order to ensure animal health and indirectly also human. It turned out that simplified nutrition in ruminants (livestock) leads to disorder (Polak and Jancova, 2005), so that the multicomponent grazing grasslands have a very positive impact on these animals. An inseparable part of the meadow is a legume component, and the presence of wild legumes such as $T$. pannonicum and $T$. alpestre ensure the quality and durability of these plant communities. 
Table 3. Secondary products of metabolism of 16 wild populations of three species of genus Trifolium

\begin{tabular}{|c|c|c|c|}
\hline Populations & $\begin{array}{l}\text { Total phenolic content } \\
\text { (mg of GA g-1 of extract) }\end{array}$ & $\begin{array}{c}\text { Flavonoid concentration } \\
\text { (mg of Ru g } \mathrm{g}^{-1} \text { of extract) }\end{array}$ & $\begin{array}{l}\text { Antioxidant activity } \\
\text { IC } 50\left(\mu \mathrm{g} \mathrm{ml}^{-1}\right)\end{array}$ \\
\hline \multicolumn{4}{|c|}{ Trifolium repens } \\
\hline CS 122 & $43.8 \pm 1.29 \mathrm{~h}$ & $42.7 \pm 1.46 \mathrm{~g}$ & $446.1 \pm 4.91 \mathrm{j}$ \\
\hline FG 020 & $34.1 \pm 1.55 \mathrm{ij}$ & $39.7 \pm 0.50$ gh & $844.7 \pm 0.40 \mathrm{~m}$ \\
\hline FG 025 & $29 \pm 0.62 \mathrm{i}$ & $31.2 \pm 1.25 \mathrm{~h}$ & $919.1 \pm 18.56 \mathrm{n}$ \\
\hline RA 089 & $42.1 \pm 1.47 \mathrm{~h}$ & $59.7 \pm 1.62 \mathrm{f}$ & $598.1 \pm 6.30 \mathrm{k}$ \\
\hline Average & 37.2 & 43.3 & 702 \\
\hline \multicolumn{4}{|c|}{ Trifolium alpestre } \\
\hline CS 068 & $77.8 \pm 0.44 \mathrm{e}$ & $130.9 \pm 4.13 \mathrm{~d}$ & $324.7 \pm 1.86 \mathrm{i}$ \\
\hline CS 091a & $86.1 \pm 3.32 \mathrm{~d}$ & $105.5 \pm 3.86 \mathrm{e}$ & $272.9 \pm 1.39 \mathrm{~h}$ \\
\hline CS105a & $38.5 \pm 0.35 \mathrm{hi}$ & $60.1 \pm 1.83 \mathrm{f}$ & $695.5 \pm 29.091$ \\
\hline Average & 67.5 & 98.8 & 431.0 \\
\hline \multicolumn{4}{|c|}{ Trifolium pannonicum } \\
\hline CS 091b & $120.1 \pm 4.94 \mathrm{a}$ & $351.6 \pm 0.22 \mathrm{a}$ & $55.0 \pm 0.76 c$ \\
\hline CS $105 \mathrm{~b}$ & $71.2 \pm 1.20 \mathrm{e}$ & $161.6 \pm 4.44 \mathrm{c}$ & $67.8 \pm 3.10 \mathrm{~d}$ \\
\hline CS 119 & $53.7 \pm 2.19 \mathrm{~g}$ & $110.8 \pm 1.17 \mathrm{e}$ & $75.4 \pm 2.38 \mathrm{e}$ \\
\hline CS 131 & $76.9 \pm 1.63 \mathrm{e}$ & $180.5 \pm 4.6 \mathrm{~b}$ & $51.0 \pm 0.48 \mathrm{~b}$ \\
\hline CS 146 & $63.3 \pm 2.79 \mathrm{f}$ & $154.3 \pm 7.06 c$ & $63.7 \pm 2.11 \mathrm{~d}$ \\
\hline ES 047 & $57.4 \pm 1.81 \mathrm{fg}$ & $110.3 \pm 3.07 \mathrm{e}$ & $67.0 \pm 1.33 \mathrm{~d}$ \\
\hline ES 059 & $57.0 \pm 2.16 \mathrm{fg}$ & $110.3 \pm 3.79 \mathrm{e}$ & $82.0 \pm 2.56 \mathrm{f}$ \\
\hline RA 100 & $94.7 \pm 3.99 c$ & $68.8 \pm 1.29 \mathrm{f}$ & $125.6 \pm 0.64 \mathrm{~g}$ \\
\hline RA 123 & $107.1 \pm 1.23 \mathrm{~b}$ & $189.3 \pm 5.28 \mathrm{~b}$ & $44.8 \pm 0.51 \mathrm{a}$ \\
\hline Average & 77.9 & 159.7 & 70.2 \\
\hline
\end{tabular}

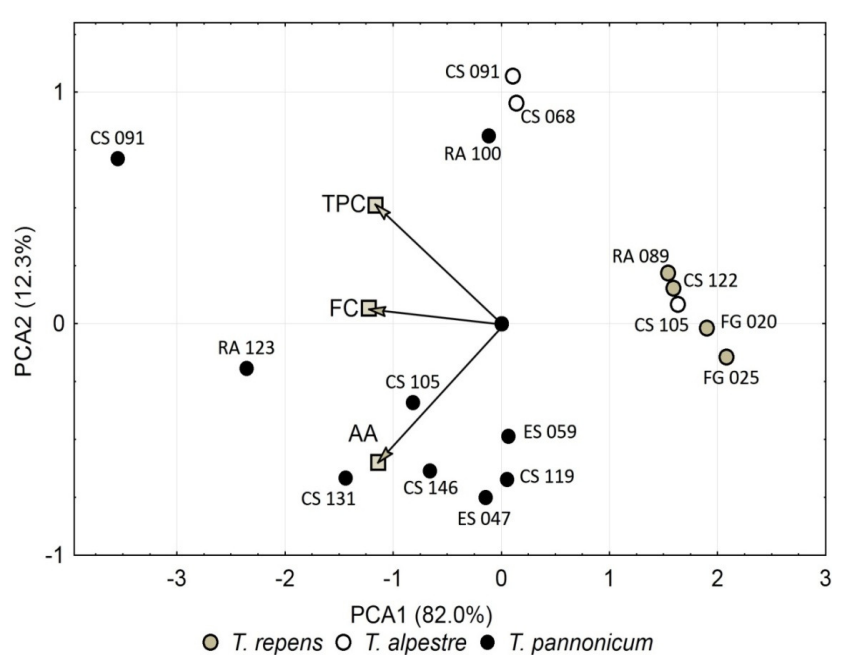

Fig. 2 PCA score and loading biplot based on the secondary products of metabolism of three Trifolium species ( TPC tital phenolic content ; FC - flavonoid concentration; AA antioxidant activity

Some of them, like $T$. pannonicum, have great potential for application in organic production. We also have demonstrated that $T$. pannonicum plants mowed in the early stages of flowering have a good quality of dry matter and a high antioxidant activity of aerial plant part. This is a long-lived species with good persistence in field conditions and good competitive ability. The mixture consisted of this type, could provide stable, long-time yield, the supply of rhizosphere with nitrogen, beneficial effect on soil structure and soil microorganism organic production. Increased content of bioactive substances in this species (Table 3) is a good indicator of resistance to diseases and pests, which is a prerequisite of organic farming with reduced use of chemicals. Due to all these positive qualities, $T$. pannonicum is the kind that could be successfully selected to obtain healthier food for livestock, as well as milk and meat for human consumption.

\section{Conclusion}

The comparative analyses of both groups of metabolites in 16 wild populations of three Trifolium species from Serbia showed the high variability of studied traits among and within the species. Based on the obtained results, some T. pannonicum populations are suitable for the further investigation programs since they have shown relatively good fodder quality and very good antioxidant activity. Population labeled as CS091 was characterized by the highest content of crude protein and the highest concentration of secondary metabolites, followed with the population RA123. All populations of $T$. repens have potential for involving in future experiments considering very good fodder quality. Because $T$. repens and $T$. alpestre are used extensively for grazing, future investigations should be focused on creating varieties with low content of isoflavones.

\section{Acknowledgments}

The authors are grateful to the Ministry of Education and Science of Republic of Serbia for sponsoring of the study within project-TR31057.

\section{References}

Abberton MT, Thomas I (2011). Genetic resources in Trifolium and their utilization in plant breeding. Plant Genetic Resources 9:38-44.

AOAC (1990). Official Methods of the Association of Official Analytical Chemists. Agricultural Chemicals, Contaminants, Drugs. Vol 1. Arlington, Virginia, USA. 
Boller B, Greene SL (2010). Genetic Resources. In: Boller B, Posselt UK, Veronesi F, (Eds). Handbook of Plant Breeding, Vol 5. Fodder and Amenity Grasses. Springer, NY pp 13-38.

Butkute B, Dabkevičiene G, Lemeziene N, Jakatas V (2012). Source of isoflavone concetration variation in perennial clover species. In: Proceedings of the 3rd International Symposium on Medicinal Plants, Their Cultivation and Aspects of Uses, Petra, Jordan pp 73-74.

Conterato IF, Dall'Agnol M, Schifino-Wittmann MT, Montardo DP, Pontalti GC, Almeida D (2010). Morphoagronomic variation in natural populations of Trifolium riograndense (Burkart). Sciencia Agricola 67(6):675-684.

Đordević N, Dinić B (2007). Hrana za životinje. Aranđelovac, Serbia (in Serbian).

Đukić JD, Stevović V, Vaskrsija RJ (2009). Livestock food production on arable land and grasslands. University of Kragujevac, Faculty of Agronomy, Čačak (in Serbian).

Ellison NW, Liston A, Steiner JJ, Williams WM, Taylor NL (2006). Molecular phylogenetics of the clover genus (Trifolium-Leguminosae). Molecular Phylogenetics and Evolution 39:688-705.

Gođevac D, Zdunić G, Šavikin K, Vajs V, MenkovićN (2008). Antioxidant activity of nine Fabaceae species growing in Serbia and Montenegro. Fitoterapia 79:185-187.

Greathead H (2003). Plants and plant extracts for improving animal productivity. Proceedings of the Nutrition Society 62:279-290.

Kicel A, Wolbis M (2006). Phenolic acids in flowers and leaves of Trifolium repens $\mathrm{L}$. and Trifolium pretense L. Herba Polonica 52(4):51-58.

Kolodziejczyk-Czepas J (2012). Trifolium species-derived substances and extracts - Biological activity and prospects for medicinal applications. Journal of Ethnopharmacology 143:1423.

Kumarasamy Y, Byres M, Cox PJ, Jaspars M, Nahar L, Sarker SD (2007). Screening seeds of some Scottish plants for free radical scavenging activity. Phytotherapy Research 21(7):615-621.

Lugić Z, Radović J, Dinić B, Jevtić G (2005). An investigation of the basic morphological and agronomic traits of Trifolium pannonicum Jack. from the wild flora of Serbia. In: Lillak R, Viiralt R, Lenke A, Geerman V (Eds). Proceedings of the 13th Symposium of European Grassland Federation. Tartu, Estoniapp 368-371.

Marković J, Dinić B, Terzić D, Andjelković S, Milenković J, Blagojević M, Ćeljaj B (2014). Macroelements in red clover (Trifolium pratense L.) relative to cow requirements. Proceedings of the $5^{\text {th }}$ Internationl scientific agricultural symposium "Agrosym 2014”, 23-26 October. Jahorina, Bosnia and Herzegovinapp 863-867.

Marshall AH, Williams TA, Abberton MT, Michaelson-Yeates TPT, Olyott P, Powell HG (2004). Forage quality of white clover (Trifolium repens $\mathrm{L}$. $) \times$ Caucasian clover (T. ambiguum $\mathrm{M}$. Bieb.) hybrids and their grass companion when grown over three harvest years. Grass and Forage Science 59:91-99.

McDonald MF, Anawar M, Koegh RG (1994). Reproductive performance of ewes after grazing on G27 red clover, a low formononetin selection in cultivar Pawera. Proceedings of the New Zealand Society of Animal Production 54:231-234.

MoorbyJM, Fraser MD, TheobaldVJ, WoodJD, Haresing W (2004). The effect of red clover (Trifolium pratense) formononetin content on liveweight gain, carcass characteristics and muscle equol content of finishinglambs. Animal Science 79(2):303-313.

Nicholls C, Altieri M (2013). Plant biodiversity enhances bees and other insect pollinators agroecosystems. A review. Agronomy for Sustainable Development 33:257-274.

Oleszek W, Stochmal A, Janda B (2007). Concentration of isoflavones and other phenolics in the aerial parts of Trifolium species. Journal of Agricultural and Food Chemistry 55:8095-8100.

Overk RC, Yao P,Chadwick LR, Nikolić D, Sun Y, Cuendet AM, Deng Y, Hedayat SA, Pauli FG, Farnshworth RN, van Breemen BR, Bolton LJ (2005). Comparison of the in vitro estrogenic activities of compounds from hops (Humulus lupulus) and red clover (Trifolium pratense). Journal of Agricultural and Food Chemistry 53:6246-6253.

Pelikán J, Vymyslický T, Nedelnik J, Gottwaldová P, Rotrekl J (2005). Increasing the diversity of forage crop communities. In: Lillak R, Viiralt R, Lenke A, Geerman V (Eds). Proceedings of the 13th Symposium of European Grassland Federation, Tartu, Estoniapp 569-573.

Petrović M, Dajić-Stevanović Z, Sokolović D, Radović J, Milenković J, Marković J (2014). Study of red clover wild populations from the territory of Serbia for the purpose of pre-selection. Genetika 46(2):471484.

Polak M, Jancova M (2005). The effects of feeding grass and grass/clover silages on dairy cows' metabolism. In: Lillak R, Viiralt R, Lenke A, Geerman V (Eds). Proceedings of the 13th Symposium of European Grassland Federation. Tartu, Estonia pp 643-647.

Ponce MA, Scervino JM, Erra-Balsells R, Ocampo JA, Godeas AM (2004). Flavonoids from shoots and roots of Trifolium repens (white clover) grown in presence or absence of the arbuscular mycorrhizal fungus Glomus intraradices. Phytochemistry 65:1925-1930.

Quettier DC, Gressier B, Vasseur J, Dine T, Brunet C, Luyckx MC (2000). Phenolic compounds and antioxidant activities of buckwheat (Fagopyrum esculentum Moench.) hulls and flour. Journal of Ethnopharmacology 72:35-42.

Rasmussen J, Yalcinb FN, Nemutlu E, Akkol EK, Suntar I, Keles H, Ina H, Calis I, Ersoz T (2012). $\mathrm{N}_{2}$-fixation and residual $\mathrm{N}$ effect of four legume species and four companion grass species. European Journal of Agronomy 36:66-74.

Sabudak T, Guler N (2009). Trifolium L. - a review on its phytochemical and pharmacological profile. Phytotherapy Research 23:439-446.

Şahin DN, Röver KU, Wrage N, Hofmann M, Isselstein J (2009). Herbage growth rates on heterogeneous swards as influenced by sward-height classes. Grass and Forage Science 64:12-18.

Singleton VL, Orthofer R, Lamuela RRM (1999). Analysis of total phenols and other oxidation substrates and antioxidants by means of FolinCiocalteu reagent. Methods in Enzymology 299:152-178.

Stanković M (2012). Biological effects of secondary metabolites of species from the genus Teucrium $\mathrm{L}$. of Serbian flora. $\mathrm{PhD}$ thesis, University of Kragujevac, Republic ofSerbia (in Serbian).

Szabo T (1987). Microevolution in Trifolium L. Sect. Stenostoma M. B. I. biometry of spontaneous and cultivated Trifolium pannonicum Jacq. Notulae Botanicae Horti Agrobotanici Cluj-Napoca 17:47-75.

TomićZ, NešićZ, Krnjaja V,Žujković M (2005). Parameters of production and quality of new cultivars of perennial leguminous plants as livestock 
208

feed. Biotechnology in Animal Husbandry 21(3-4):89-96.

Vasiljević S, Ćupina B, Krstić Đ, Pataki I, Katanski S, Milošević B (2011). Seasonal changes of proteins, structural carbohydrates, fats and minerals in herbage dry matter of red clover (Trifolium pratense L.). Biotechnology in Animal Husbandry 27(4):1543-1550.

Vasiljević S, Milić D, Mikić A (2009). Chemical attributes and quality improvement of forage legumes. Biotechnology in Animal Husbandry 25:493-504.

Vilčinskas E, Dabkevičienè G (2010). Yield structure and dry matter qualitative characteristics of clover (Trifolium spp.) species. Žemès ūkio mokslai 17(1-2):18-24(in Lithuanian).

Vilčinskas E, Dabkevičenè G (2009). Pirmujų auginimo metų dobilų (Trifolium spp.) rūšių kiekybiniai ir kokybiniai požymiai. ŽemdirbystèAgriculture 96(4):170-180 (in Lithuanian).
VlaisavljevićS, Kaurinović B, Popović M, Đurendić-Brenesel M, Vasiljević B, Cvetković D, Vasiljević S (2014). Trifolium pratense L. as a potential natural antioxidant. Molecules 19:713-725.

Wu Q, Wang M, Simon EJ (2003). Determination of isoflavones in red clover and related species by high-performance liquid chromatography combined with ultraviolet and mass spectrometric detection. Journal of Chromatography A 1016:195-209.

Zohary M, Heller D (1984). The Genus Trifolium. The Israel Academy of Sciences and Humanities, Jerusalem, Israel. 